\title{
Characterization of fat globules and milk fat globule membrane proteins in milk of different yak breeds
}

\author{
Shenghua $\mathrm{HE}^{1}$, Ying $\mathrm{MA}^{1 *}$, Jiaqi $\mathrm{WANG}^{2}$, Qiming $\mathrm{LI}^{2}$, Shanhu TANG ${ }^{3}$, \\ Changhui ZHAO ${ }^{1}$, Haimei $\mathrm{LI}^{1}$, Jean-Louis Maubois ${ }^{4}$ \\ ${ }^{1}$ School of Food Science and Engineering, Harbin Institute of Technology, Harbin 150090, P.R. China \\ ${ }^{2}$ New Hope Dairy Holding Limited Company, Sichuan 610041, P.R. China \\ ${ }^{3}$ School of Food Science and Engineering, Southwest University for Nationalities, \\ Sichuan 610041, P.R. China \\ ${ }^{4}$ INRA, UMR1253, F-35042 Rennes, France
}

Received 28 November 2009 - Revised 2nd April 2010 - Accepted 2nd April 2010

Published online 28 May 2010

\begin{abstract}
The objective of this work was to characterize the fat globule and milk fat globule membrane (MFGM) proteins in Maiwa $(n=6)$, Gannan $(n=4)$ and Zhongdian yak whole milks $(n=4)$. Fat globule size distribution and specific fat surface area of whole yak milk were determined using a laser diffraction particle size analyzer. The average specific fat surface area of Gannan yak milk $\left(2.05 \mathrm{~m}^{2} \cdot \mathrm{mg}^{-1}\right)$ and Zhongdian yak milk $\left(2.01 \mathrm{~m}^{2} \cdot \mathrm{mg}^{-1}\right)$ was higher $(P<0.05)$ than that of Maiwa yak milk $\left(1.92 \mathrm{~m}^{2} \cdot \mathrm{mg}^{-1}\right)$. The total protein content of MFGM and surface protein coverage of fat globule in Maiwa yak milk $\left(11.12 \mathrm{mg} \cdot \mathrm{g}^{-1}\right.$ fat and $5.67 \mathrm{mg} \cdot \mathrm{m}^{-2}$, respectively) and Gannan yak milk $\left(12.24 \mathrm{mg} \cdot \mathrm{g}^{-1}\right.$ fat and $5.97 \mathrm{mg} \cdot \mathrm{m}^{-2}$, respectively) were higher $(P<0.05)$ than that of Zhongdian yak milk $\left(9.72 \mathrm{mg} \cdot \mathrm{g}^{-1}\right.$ fat and $4.81 \mathrm{mg} \cdot \mathrm{m}^{-2}$, respectively). Protein components in the MFGM of yak milk were analyzed using an Ultrascan XL laser densitometer and an LKB 2400 GelScanXL software program. No major differences $(P>0.05 \%)$ in the protein patterns on the SDS gel were observed among the MFGM of Maiwa yak, Gannan yak and Zhongdian yak, with the exception of mucin 1 and butyrophilin which were significantly lower $(P<0.05)$ in the MFGM of Zhongdian yak milk.
\end{abstract}

fat globule / surface protein composition / yak milk / breed / milk fat globule membrane

摘要 - 不同品种牦牛奶脂肪球和脂肪球膜蛋白特性。本文的主 要 目 的是研 究麦 洼 $(n=6)$ 、甘南 $(n=4)$ 和中甸牦牛奶 $(n=4)$ 的脂肪球特性以及脂肪球膜 (MFGM) 蛋 白的组成。牦牛奶的脂肪球粒径分布和比表面积用激光衍射粒度大小分析仪测定。实验 结果表明: 甘南牦牛奶脂肪球比表面积 $\left(2.05 \mathrm{~m}^{2} \cdot \mathrm{mg}^{-1}\right)$ 和中甸牦牛奶脂肪球比表面积 $\left(2.01 \mathrm{~m}^{2} \cdot \mathrm{mg}^{-1}\right)$ 明显高于 $(P<0.05)$ 麦洼牦牛奶脂肪球比表面积 $\left(1.92 \mathrm{~m}^{2} \cdot \mathrm{mg}^{-1}\right)$ 。麦洼牦牛 奶 MFGM 总蛋白 $\left(11.12 \mathrm{mg} \cdot \mathrm{g}^{-1}\right)$ 脂肪和脂肪球的表面蛋白覆盖量 $\left(5.67 \mathrm{mg} \cdot \mathrm{m}^{-2}\right)$ 以及甘南 牦牛奶 MFGM 总蛋白 $\left(12.24 \mathrm{mg} \cdot \mathrm{g}^{-1}\right)$ 脂肪和脂肪球的表面蛋白覆盖量 $\left(5.97 \mathrm{mg} \cdot \mathrm{m}^{-2}\right)$ 要明 显高于 $(P<0.05)$ 中甸牦牛奶 MFGM 总蛋白 $\left(9.72 \mathrm{mg} \cdot \mathrm{g}^{-1}\right.$ 脂肪 $)$ 和脂肪球的表面蛋白覆 盖量 $\left(4.81 \mathrm{mg} \cdot \mathrm{m}^{-2}\right)$ 。特牛奶 MFGM 蛋白的组成分析采用Ultrascan XL 激光显像密 度仪和 LKB $2400 \mathrm{GelScanXL}$ 软件程序来完成。实验结果表明: 麦洼牦牛奶、甘南牦牛奶

*Corresponding author (通讯作者): maying@hit.edu.cn 
和中甸牦牛奶 MFGM 蛋白除了黏液素 (MUC1) 和嗜乳蛋白 (BUT) 的含量存在差异 外 $(P>0.05)$, 而 SDS-PAGE 显示三种牦牛奶 MFGM 蛋白的主要组份没有显著差 异 $(P>0.05)$ 。

\section{脂肪球特性 / 蛋白质组成 / 牦牛奶 / 不同品种 / 奶脂肪球膜}

Résumé - Caractérisation des globules gras et des protéines de membrane de globule gras du lait de différentes races de yak. L'objectif de ce travail était de caractériser les globules gras et les protéines de membrane de globule gras du lait entier de yak de races Maiwa $(n=6)$, Gannan $(n=4)$ et Zhongdian $(n=4)$. La distribution de taille des globule gras et la surface spécifique du lait entier de yak ont été déterminées par mesure de diffraction laser. La surface spécifique moyenne des globules gras du lait de yak de race Gannan $\left(2,05 \mathrm{~m}^{2} \cdot \mathrm{mg}^{-1}\right)$ et de race Zhongdian $\left(2,01 \mathrm{~m}^{2} \cdot \mathrm{mg}^{-1}\right)$ était significativement plus élevée $(P<0,05)$ que celle obtenue pour le lait de yak de race Maiwa $\left(1,92 \mathrm{~m}^{2} \cdot \mathrm{mg}^{-1}\right)$. La teneur en protéines totales de la membrane du globule gras du lait de yak et la couverture en protéine de surface étaient plus élevées $(P<0,05)$ dans le lait de yak de race Maiwa (respectivement $11,12 \mathrm{mg} \cdot \mathrm{g}^{-1}$ de matière grasse et $5,67 \mathrm{mg} \cdot \mathrm{m}^{-2}$ ) et du lait de yak de race Gannan (respectivement $12,24 \mathrm{mg} \cdot \mathrm{g}^{-1}$ de matière grasse et $5,97 \mathrm{mg} \cdot \mathrm{m}^{-2}$ ) par rapport au lait de yak de race Zhongdian (respectivement $9,72 \mathrm{mg} \cdot \mathrm{g}^{-1}$ de matière grasse et $4,81 \mathrm{mg} \cdot \mathrm{m}^{-2}$ ). Les composants protéiques de la membrane de globule gras du lait de yak ont été analysés par densitométrie laser Ultrascan XL à l'aide du logiciel GelScanXL LKB 2400. Aucune différence $(P>0,05)$ n'a été observée dans les profils protéiques des gels SDS obtenus à partir des membranes de globule gras du lait de yak des trois races, à l'exception d'un pourcentage significativement plus faible $(P<0,05)$ en mucine 1 et en butyrophiline pour le lait de yak de race Zhongdian.

globule gras / protéine de surface / lait de yak / race / membrane de globule gras

\section{INTRODUCTION}

Yak can survive in temperatures as low as $-40{ }^{\circ} \mathrm{C}$ and elevation ranging from 3000 to $5000 \mathrm{~m}$, but cannot stand at temperatures above $25{ }^{\circ} \mathrm{C}$ and normal atmospheric pressure. Statistical data showed that China has 14 million yaks and accounts for 95\% of total number of the world [15]. The dominating yak species in China are Maiwa yak, Zhongdian yak and Gannan yak; they feed themselves on the native forages all year round without any supplementation. This cold climate and high elevation-loving animal produces milk with a higher fat $(6-10 \%)$ and protein $(5.5 \%)$ content when compared to bovine milk [11].

In all types of milks, fat droplets are surrounded by a membrane named milk fat globule membrane (MFGM). MFGM mainly comprises proteins and phospholipids. There are over 40 identified different proteins, ranging in molecular weight from
15 to $240 \mathrm{~kg} \cdot \mathrm{mol}^{-1}$, among which at least six are glycoproteins [7]. The major proteins have molecular weights of $155,67,50$ and $49 \mathrm{~kg} \cdot \mathrm{mol}^{-1}$, identified as xanthine oxidase (XO), butyrophilin (BUT), Periodic Acid Schiff 6 (PAS 6) and Periodic Acid Schiff 7 (PAS 7), respectively [6]. Moreover, it is assumed that some of the MFGM proteins possess specific nutritional properties [5]. As such, MFGM material and MFGM components have been isolated and characterized as valuable ingredients for application into new food products. However, further work is needed on the quantification of the different MFGM components in various dairy products and on the optimization of food-grade downstream extraction and production processes from milk or from its derivatives.

In contrast to the extensive work done on bovine milk, to our knowledge, no information is available on protein composition of yak MFGM. The aim of this study was 
Table I. Sample information.

\begin{tabular}{llcc}
\hline Breeds & Source of milk samples & Elevation $(\mathrm{m})$ & Number of samples analyzed \\
\hline Maiwa yak & Sichuan province of China & $3000-4000$ & 6 \\
Zhongdian yak & Yunnan province of China & $3000-3400$ & 4 \\
Gannan yak & Gansu province of China & $3000-5000$ & 4 \\
\hline
\end{tabular}

therefore to detail protein composition of yak MFGM.

\section{MATERIALS AND METHODS}

\subsection{Materials}

Yak milk samples produced by three pure yak breeds were collected in autumn, the detailed information of which is given in Table I. The cream was separated according to the method of Ye et al. [13]. The cream was washed with a solution of $\mathrm{KCl}$ $\left(1.5 \mathrm{~g} \cdot \mathrm{L}^{-1}\right)$ within $3 \mathrm{~h}$ of collection and then the cream was held at $4{ }^{\circ} \mathrm{C}$ overnight before further processing and analysis.

All the chemicals used were of analytical grade obtained from China Chemicals Reagent Co. (Harbin, China) or Sigma Chemical Co. (St. Louis, MO, USA) unless specified otherwise.

\subsection{Determination of average fat globule size and specific surface area of whole yak milk}

Fat globule size distribution was determined by a Laser Diffraction Particle Size Analyzer (Dandong Bettersize Instruments, Ltd., Liaoning, China). The casein micelles were dissociated by diluting the sample to $1 / 1000$ in EDTA buffered saline (EDTA, $35 \mathrm{mmol} \cdot \mathrm{L}^{-1}$, $\mathrm{pH}$ 7.0) prior to measurement. The refractive indices used were 1.458 and 1.460 for milk fat at 633 and $466 \mathrm{~nm}$, respectively, and the refractive index was 1.33 for water [9]. Standard parameters were calculated by the software: the volumic average diameter $d_{43}=\sum\left(v_{\mathrm{i}} \cdot d_{\mathrm{i}}\right) / \sum v_{\mathrm{i}}$ (where $v_{\mathrm{i}}$ is the volume of globules in a size class of average diameter, $\left.d_{\mathrm{i}}\right)$, The volume-surface average diameter $d_{32}=\sum v_{\mathrm{i}} / \sum\left(v_{\mathrm{i}} / d_{\mathrm{i}}\right)$ and the specific fat surface area $S=6 \rho^{-1} d_{32}^{-1}$, where $\rho$ is the milk fat density.

\subsection{Determination of washed cream protein content}

The total protein content of cream, washed with the solution of $\mathrm{KCl}$ $\left(1.5 \mathrm{~g} \cdot \mathrm{L}^{-1}\right)$, was determined using the Kjeldahl method (AOAC, 1974) by determining total nitrogen and multiplying it by a factor of 6.38 .

\subsection{Isolation of milk fat globule membrane material}

Samples for MFGM were prepared from $1 \mathrm{~L}$ of fresh unpasteurized cream using the acidification method reported by Kanno and Kim [3]. The cream was washed three times with three volumes of Milli-Q water $\left(38^{\circ} \mathrm{C}\right)$ in a cream separator. The washed cream was allowed to crystallize for $4 \mathrm{~h}$ at $4{ }^{\circ} \mathrm{C}$ before churning through the use of a mixer. The resulting butter and buttermilk were separated using a sieve. The buttermilk was adjusted to $\mathrm{pH} 4.8$ using hydrochloric acid $\left(1 \mathrm{~mol} \cdot \mathrm{L}^{-1}\right)$ in order to allow MFGM to precipitate out. The precipitated MFGM was centrifuged at $10000 \times \mathrm{g}$, and MFGM pellet and supernatant were collected. The $\mathrm{pH}$ of both resuspended MFGM pellet (in water) and supernatant was adjusted to 6.8 using sodium hydroxide $\left(1 \mathrm{~mol} \cdot \mathrm{L}^{-1}\right)$. 
Table II. Characteristics of yak milk fat globule from different yak breeds.

\begin{tabular}{lccc}
\hline Yak breeds & $\begin{array}{c}\text { Maiwa yak } \\
(n=6)\end{array}$ & $\begin{array}{c}\text { Gannan yak } \\
(n=4)\end{array}$ & $\begin{array}{c}\text { Zhongdian yak } \\
(n=4)\end{array}$ \\
\hline$d_{43}(\mu \mathrm{m})^{1}$ & $4.34 \pm 0.04^{\mathrm{a}}$ & $4.16 \pm 0.03^{\mathrm{a}}$ & $4.10 \pm 0.03^{\mathrm{b}}$ \\
$d_{32}(\mu \mathrm{m})^{2}$ & $3.04 \pm 0.06^{\mathrm{a}}$ & $2.84 \pm 0.01^{\mathrm{b}}$ & $2.90 \pm 0.01^{\mathrm{b}}$ \\
Specific fat surface area $\left(\mathrm{m}^{2} \cdot \mathrm{mg}^{-1}\right)$ & $1.92 \pm 0.03^{\mathrm{a}}$ & $2.05 \pm 0.01^{\mathrm{b}}$ & $2.01 \pm 0.01^{\mathrm{b}}$ \\
Total protein in MFGM $\left(\mathrm{mg} \cdot \mathrm{g}^{-1}\right.$ fat $)$ & $11.12 \pm 0.12^{\mathrm{a}}$ & $12.24 \pm 0.09^{\mathrm{a}}$ & $9.72 \pm 0.26^{\mathrm{b}}$ \\
Surface protein coverage of milk fat globule & $5.67 \pm 0.07^{\mathrm{a}}$ & $5.97 \pm 0.08^{\mathrm{a}}$ & $4.81 \pm 0.15^{\mathrm{b}}$ \\
$\left(\mathrm{mg} \cdot \mathrm{m}^{-2}\right)$ & & & \\
\hline
\end{tabular}

${ }^{1} d_{43}=\sum\left(v_{\mathrm{i}} \cdot d_{\mathrm{i}}\right) / \sum v_{\mathrm{i}}$ (where $v_{\mathrm{i}}$ is the volume of globules in a size class of average diameter, $d_{\mathrm{i}}$ ).

${ }^{2} d_{32}=\sum v_{\mathrm{i}} / \sum\left(v_{\mathrm{i}} / d_{\mathrm{i}}\right)$ (where $v_{\mathrm{i}}$ is the volume of globules in a size class of average diameter, $d_{\mathrm{i}}$ ).

Data are means \pm sample standard deviations.

${ }_{\mathrm{a}, \mathrm{b}}$ Different superscripts within a row indicate significant differences $(P \leq 0.05)$.

The resuspended MFGM pellet and supernatant were freeze dried and stored at $-80{ }^{\circ} \mathrm{C}$ before analysis.

\subsection{Electrophoresis}

Protein composition of MFGM from washed creams was determined by SDSPAGE. Samples were suspended in $0.5 \mathrm{~mL}$ of reducing buffer $\left(6 \%\right.$ Tris- $0.5 \mathrm{~mol} \cdot \mathrm{L}^{-1}$, $10 \%$ glycerol, $5 \% \beta$-mercaptoethanol, $2 \%$ SDS and $0.05 \%$ bromophenol blue). Samples were heated at $95{ }^{\circ} \mathrm{C}$ for $5 \mathrm{~min}$ and then centrifuged at $2500 \times \mathrm{g}$ for $30 \mathrm{~min}$ in order to remove the fat from the sample. Supernatants $(10 \mu \mathrm{L})$ were loaded onto $10 \%$ SDS-polyacrylamide gels. Molecular mass markers ranging from 30 to $200 \mathrm{~kg} \cdot \mathrm{mol}^{-1}$ (TransGen, Biotech, China) and milk proteins were run at $200 \mathrm{~V}$. Protein bands were stained with a solution of Coomassie Brilliant Blue R-250. Gels were destained with a solution of methanol and glacial acetic acid at concentrations of 160 and $10 \mathrm{~mL} \cdot \mathrm{L}^{-1}$, respectively. Scanned images of the destained gels were analyzed using the ImageMaster software (Amersham Pharmacia Biotech, Newcastle upon Tyne, UK). The apparent molecular mass $(\mathrm{Mw})$ of the bands on the SDS-PAGE was estimated from the mobility of proteins in the gel when compared with the mobility of the molecular mass markers. The gels were scanned using an Ultrascan XL laser densitometer, and the results were analyzed using an LKB 2400 GelScanXL software program (LKB Produkter AB, Bromma, Sweden) to obtain quantitative results.

\subsection{Statistical analysis}

Statistical analysis was performed using $t$ test. A value of $P \leq 0.05$ was considered significant. The results were achieved through the SPSS version 9.0 windows program (SPSS, Inc., 1998, Chicago, IL, USA).

\section{RESULTS AND DISCUSSION}

\subsection{Characterization of fat globule from different yak breeds}

The characterization of fat globule of three yak breeds is given in Table II. The size distributions of the fat globules from three yak breeds are presented in Figure 1. The volumic average diameter $d_{43}$ of Maiwa yak milk $(4.34 \mu \mathrm{m})$ and Gannan yak milk $(4.16 \mu \mathrm{m})$ was higher $(P<0.05)$ than that of Zhongdian yak milk $(4.10 \mu \mathrm{m})$. The average specific fat surface area of Gannan yak milk $\left(2.05 \mathrm{~m}^{2} \cdot \mathrm{mg}^{-1}\right)$ and Zhongdian yak milk $\left(2.01 \mathrm{~m}^{2} \cdot \mathrm{mg}^{-1}\right)$ was higher $(P<0.05)$ than that of Maiwa yak milk $\left(1.92 \mathrm{~m}^{2} \cdot \mathrm{mg}^{-1}\right)$. The total protein content 


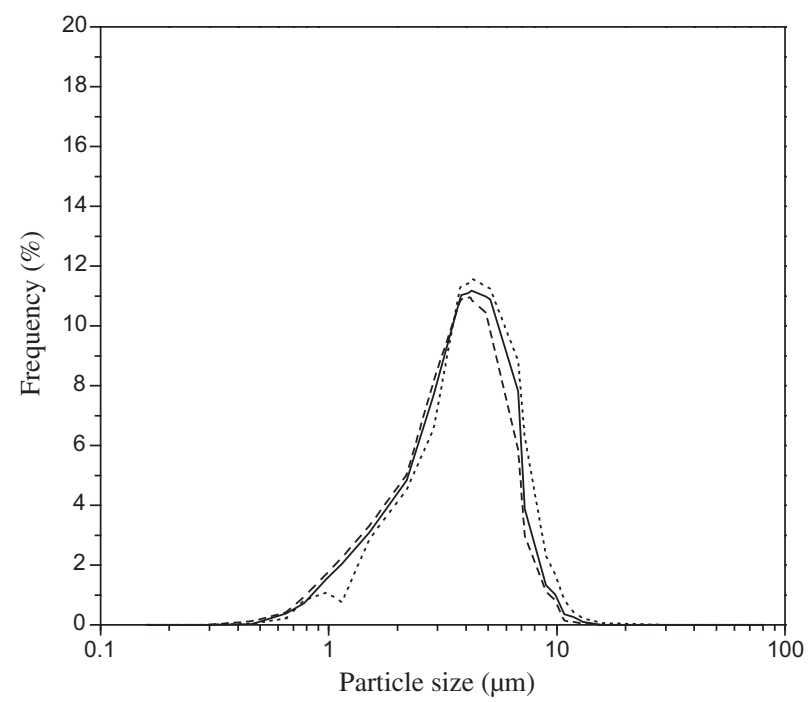

Figure 1. Particle size distribution of fat globule from Maiwa yak milk (...), Gannan yak milk (-) and Zhongdian yak milk (--).

of MFGM in Maiwa yak milk $\left(11.12 \pm 0.12 \mathrm{mg} \cdot \mathrm{g}^{-1}\right.$ fat $)$ and Gannan yak milk (12.24 $\pm 0.09 \mathrm{mg} \cdot \mathrm{g}^{-1}$ fat) was significantly higher $(P<0.05)$ than that of Zhongdian yak milk $\left(9.72 \pm 0.26 \mathrm{mg} \cdot \mathrm{g}^{-1}\right.$ fat). The values for total protein content of MFGM in Maiwa yak milk and Gannan yak milk were well similar to those found in bovine milk as reported by Patton and Huston [12] (10 $\mathrm{mg} \cdot \mathrm{g}^{-1}$ of fat globules) and Mulder and Walstra [10] (9 $\mathrm{mg} \cdot \mathrm{g}^{-1}$ of fat globules). The surface protein coverage in the fat globule of Maiwa yak milk $\left(5.67 \pm 0.07 \mathrm{mg} \cdot \mathrm{m}^{-2}\right)$ and Gannan yak milk $\quad\left(5.97 \pm 0.08 \mathrm{mg} \cdot \mathrm{m}^{-2}\right) \quad$ was higher $(P<0.05)$ than those of Zhongdian yak milk $\left(4.81 \pm 0.15 \mathrm{mg} \cdot \mathrm{m}^{-2}\right)$. The surface protein coverage in the milk fat globule of the three yak breeds was higher than that reported for bovine milk by Ye et al. [13] $\left(1.85 \mathrm{mg} \cdot \mathrm{m}^{-2}\right)$ and lower than those indicated by Mulder and Walstra $\left(9 \mathrm{mg} \cdot \mathrm{m}^{-2}\right)$ [10]. The higher surface protein coverage could be due to the combination of lower specific fat surface area and higher total protein of Maiwa yak, Gannan yak and Zhongdian yak milk fat globule which were different from those of bovine milk reported by Ye et al. [13] and Mulder and Walstra [10].

\subsection{MFGM proteins of different yak breeds}

Figure 2 illustrates the protein patterns of MFGM, isolated from Maiwa yak, Gannan yak and Zhongdian yak, determined by SDS-PAGE (10\% acrylamide) under reducing conditions (Figs. 2A-2C). There were five major protein bands, ranging in molecular weight from 47 to $225 \mathrm{~kg} \cdot \mathrm{mol}^{-1}$. The apparent molecular mass of major bands on SDSPAGE was estimated by comparison with the mobility of molecular weight standards. The approximate quantities of these proteins in the MFGM were determined by scanning the stained bands. The major bands corresponded to mucin 1 (MUC 1, Mw, 

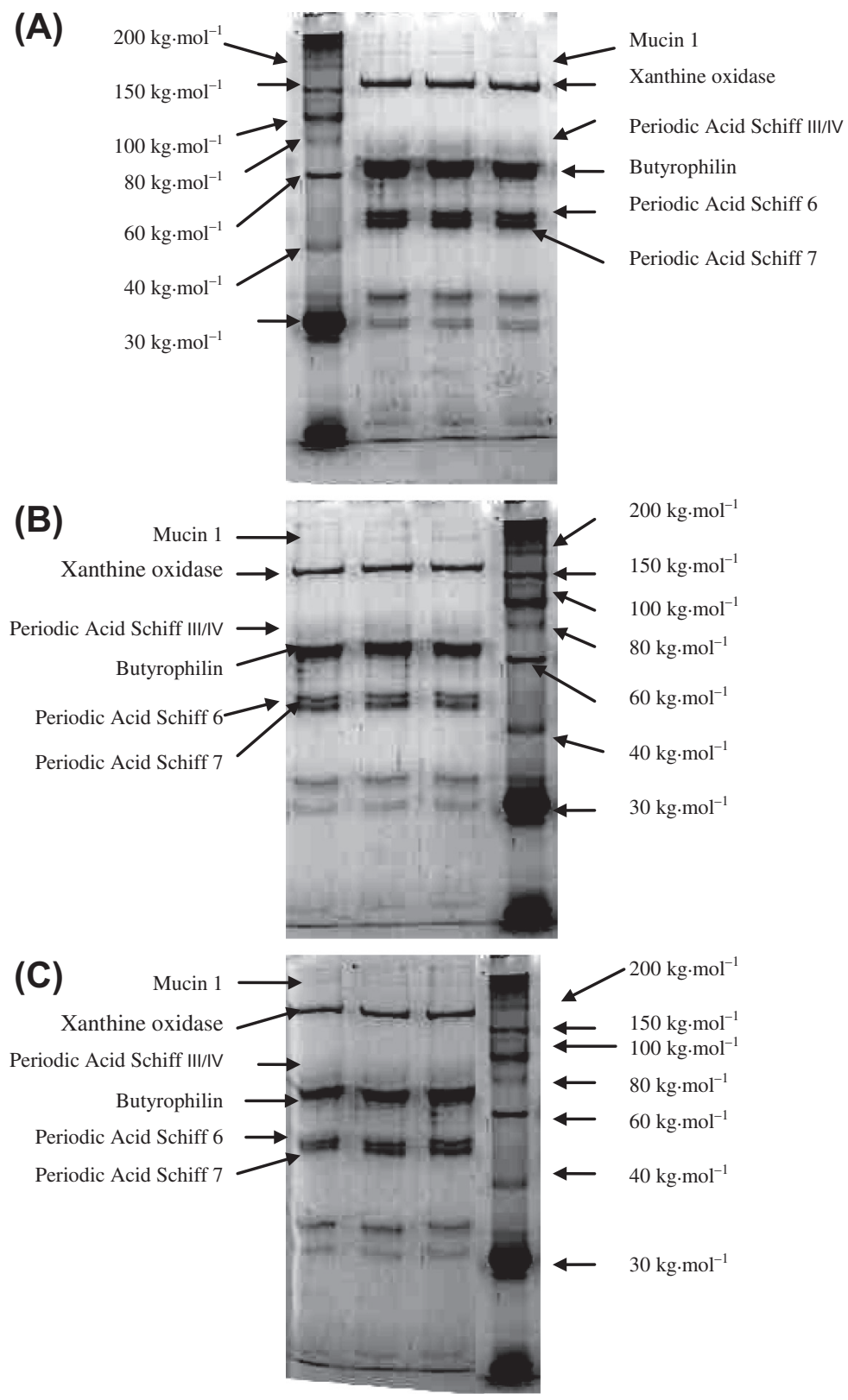

Figure 2. SDS-PAGE patterns $(10 \%$ acrylamide gel), obtained under reducing conditions, of MFGM material from fresh whole yak milk. MFGM from Maiwa yak milk (A); MFGM from Gannan yak milk (B) and MFGM from Zhongdian yak milk (C). Membrane proteins are named according to Mather [6]. 
Table III. Protein components in the MFGM obtained from different yak breeds.

\begin{tabular}{|c|c|c|c|c|}
\hline \multirow[t]{2}{*}{ Proteins } & \multirow[b]{2}{*}{$\begin{array}{l}\text { Molecular weight } \\
\left(\mathrm{kg} \cdot \mathrm{mol}^{-1}\right)\end{array}$} & \multicolumn{3}{|c|}{ Percentage of total protein in MFGM $(\%)^{1}$} \\
\hline & & $\begin{array}{c}\text { Maiwa yak milk } \\
\quad(n=6)\end{array}$ & $\begin{array}{c}\text { Gannan yak milk } \\
(n=4)\end{array}$ & $\begin{array}{l}\text { Zhongdian yak milk } \\
(n=4)\end{array}$ \\
\hline Mucin 1 & 225.6 & $4.87 \pm 0.54^{\mathrm{a}}$ & $4.54 \pm 0.21^{\mathrm{a}}$ & $3.87 \pm 0.27^{\mathrm{b}}$ \\
\hline Xanthine oxidase & 157.4 & $16.31 \pm 0.10^{\mathrm{a}}$ & $16.18 \pm 0.87^{\mathrm{a}}$ & $16.27 \pm 0.74^{\mathrm{a}}$ \\
\hline $\begin{array}{l}\text { Periodic Acid } \\
\text { Schiff III/IV }\end{array}$ & $78-98$ & $3.81 \pm 0.45^{\mathrm{a}}$ & $3.09 \pm 0.33^{\mathrm{a}}$ & $3.21 \pm 0.29^{\mathrm{a}}$ \\
\hline Butyrophilin & 67.5 & $25.43 \pm 0.63^{\mathrm{a}}$ & $25.23 \pm 0.74^{\mathrm{a}}$ & $22.32 \pm 0.91^{\mathrm{b}}$ \\
\hline $\begin{array}{l}\text { Periodic Acid } \\
\text { Schiff } 6\end{array}$ & 50.2 & $13.45 \pm 0.18^{\mathrm{a}}$ & $13.01 \pm 0.43^{\mathrm{a}}$ & $14.09 \pm 0.24^{\mathrm{a}}$ \\
\hline $\begin{array}{l}\text { Periodic Acid } \\
\text { Schiff } 7\end{array}$ & 47.8 & $13.46 \pm 0.09^{\mathrm{a}}$ & $13.04 \pm 0.48^{\mathrm{a}}$ & $14.94 \pm 0.11^{\mathrm{a}}$ \\
\hline $\begin{array}{l}\text { Other minor } \\
\text { proteins }\end{array}$ & & $22.67 \pm 3.00^{\mathrm{a}}$ & $23.91 \pm 3.20^{\mathrm{a}}$ & $25.75 \pm 1.80^{\mathrm{a}}$ \\
\hline
\end{tabular}

${ }^{1}$ Data are based solely on staining intensity.

Data are means \pm sample standard deviations.

${ }_{\mathrm{a}, \mathrm{b}}$ Different superscripts within a row indicate significant differences $(P \leq 0.05)$.

$225.6 \mathrm{~kg} \cdot \mathrm{mol}^{-1}$ ), the largest protein of the MFGM. Many studies on cow's milk have shown that the apparent molecular weight $(\mathrm{Mw})$ of this protein ranges from 170 to $225 \mathrm{~kg} \cdot \mathrm{mol}^{-1}$ depending on the breed [6]. Molecular weight (Mw) of yak other MFGM proteins determined in this study was as follows: xanthine oxidase (Mw, $157.4 \mathrm{~kg} \cdot \mathrm{mol}^{-1}$ ), PAS III/IV (Mw, 78-98 kg: $\mathrm{mol}^{-1}$ ), butyrophilin (Mw, $\left.67.5 \mathrm{~kg} \cdot \mathrm{mol}^{-1}\right)$, PAS $6\left(\mathrm{Mw}, 50.2 \mathrm{~kg} \cdot \mathrm{mol}^{-1}\right)$ and PAS $7\left(\mathrm{Mw}, 47.8 \mathrm{~kg} \cdot \mathrm{mol}^{-1}\right)$. The major protein bands on SDS-PAGE ( $10 \%$ acrylamide) in MFGM of the three yak breeds showed similar electrophoretical patterns compared with those from MFGM of bovine milk described by Keenan and Dylewski [4] and Ye et al. [13], who reported that the major protein bands corresponded to mucin 1, xanthine oxidase, butyrophilin, PAS 6 and PAS 7. A faint band with molecular weight of $62 \mathrm{~kg} \cdot \mathrm{mol}^{-1}$ was also observed, near butyrophilin.

There were no qualitative electrophoretical differences observed between the MFGM of Maiwa yak, Gannan yak and Zhongdian yak milks (Figs. 2A-2C).
However, there were quantitative differences $(P<0.05)$ in the percentage of some of the protein components among the milk of three yak breeds (Tab. III). There were five major protein bands on SDS-PAGE in the MFGM of three yak breeds. There were no differences observed $(P>0.05)$ in mucin 1, xanthine oxidase, PAS 6 and PAS 7 in the MFGM of the three yak breeds, but the percentages of mucin 1 and butyrophilin were significantly higher $(P<0.05)$ in Maiwa yak and Gannan yak MFGM than in Zhongdian yak MFGM. These values could be due to a higher content of total MFGM proteins in Maiwa yak and Gannan yak milks. To our knowledge, there was no report describing difference between breeds for both bovine MUC1 and butyrophilin. On the other hand, Ye et al. [13] have reported differences in xanthine oxidase, butyrophilin and total MFGM proteins according to the stage of lactation and cow's feeding. It must also be pointed out that the percentages reported in Table III are based on staining intensity, which is known to be varying with protein species and consequently, giving 
enhancement or lowering of the observed differences. The proportion (Tab. III) observed between major proteins $(70 \%)$ and minor proteins $(30 \%)$ was similar for all milks. Xanthine oxidase and butyrophilin, respectively, accounted for $14 \%$ and $18-22 \%$ of the MFGM proteins in three yak breeds. In cow's milk, concentration of xanthine oxidase and butyrophilin varies within the lactation period, but they were present in constant molar proportions of about $1: 4[8,14]$. On the other hand, the relative proportion of these proteins shows interspecies differences, for example, in human milk, the level of xanthine oxidase is much higher than that of butyrophilin [1, 2] and in goat's milk, proportion is $1: 1$ [14]. Our results showed a proportion of about $1: 2$ between these two proteins. No significant variation $(P>0.05)$ was observed among Maiwa, Zhongdian and Gannan yak milks for PAS 6 and PAS 7. The observed faint bands of Periodic Acid Schiff III (PAS III) and Periodic Acid Schiff IV (PAS IV) may be due to the loose association of these proteins to MFGM which maybe has led to a removal from the membrane during washing with salt solutions.

\section{CONCLUSION}

In the present study, breeds variations in fat globule membrane protein components were observed among three yak breeds. A significant difference $(P<0.05)$ was found in the percentage of mucin 1 and butyrophilin of the MFGM components among the milk of the three yak breeds. Based on these data, there were some differences in fat globule characterization and protein components of MFGM among different yak breeds.

Acknowledgments: This work was funded by National Nature Science Foundation of China (No. 30871953). The authors thank New Hope Dairy Holding Co. Ltd. for milk samples and the Southwest University for Nationalities of Sichuan for laboratory analyses.

\section{REFERENCES}

[1] Freudenstein C., Keenan T.W., Eigel W.N., Sasaki M., Stadler J., Franke W.W., Preparation and characterization of the inner coat material associated with fat globule membranes from bovine and human milk, Exp. Cell Res. 118 (1979) 277-294.

[2] Houlihan A.V., Goddard P.A., Nottingham S.M., Kitchen B.J., Masters C.J., Interactions between the bovine milk fat globule membrane and skim milk components on heating whole milk, J. Dairy Res. 59 (1992) 187-195.

[3] Kanno C., Kim D.H., A simple procedure for the preparation of bovine milk fat globule membrane and a comparison of its composition enzymatic activities, and electrophoretic properties with those prepared by other methods, Agric. Biol. Chem. 54 (1990) 2845-2854.

[4] Keenan T.W., Dylewski D.P., Intracellular origin of milk lipid globules and the nature of structure of milk fat globule membrane, Advanced Dairy Chemistry, Lipids, Vol. 2 Chapman \& Hall, London, UK, 1995.

[5] Keenan T.W., Patton S., Jensen R.G., The structure of milk: A. The milk lipid globule membrane, in: Handbook of Milk Composition, Academic Press, New York, USA, 1995, pp. 5-50.

[6] Mather I.H., A review and proposed nomenclature for major proteins of the milk-fat globule membrane, J. Dairy Sci. 83 (2000) 203-247.

[7] McPherson A.V., Dash M.C., Kitchen B.J., Isolation and composition of milk fat globule membrane material. I. From pasteurized milks and creams, J. Dairy Res. 51 (1984) 279-287.

[8] McPherson A.V., Kitchen B.J., Reviews of the progress of dairy science: the bovine milk fat globule membrane-its formation composition, structure and behaviour in milk and dairy products, J. Dairy Res. 50 (1983) 107-133.

[9] Michalski M., Briard V., Michel F., Apparent zeta-potential as a tool to assess mechanical damages to the milk fat globule membrane, Lait 81 (2001) 787-796. 
[10] Mulder H., Walstra P., The Milk Fat Globule - Emulsion Science as Applied to Milk Products and Comparable Foods, Commonwealth Agricultural Bureaux, Slough, England, UK, 1974.

[11] Neupaney D., Kim J., Ishioroshi M., Samejima K., Study on composition of Nepalese cheeses yak milk and yak cheese whey, Milk Sci. 46 (1997) 95-102.

[12] Patton S., Huston G.E., The milk fat globule membrane, Lipids 21 (1986) 170-174.

[13] Ye A., Singh H., Taylor M.W., Anema S., Characterization of protein components of natural and heat-treated milk fat globule membranes, Int. Dairy J. 12 (2002) 393402.

[14] Zamora A., Guamis B., Trujillo A.J., Protein composition of caprine milk fat globule membrane, Small Rumin. Res. 82 (2009) 122-129.

[15] Zhong J.-C., Chen Z.-H., Zhao S.-J., Xiao Y.-P., Classification of ecological types of the Chinese yak, Acta Ecol. Sin. 26 (2006) 2068-2072. 